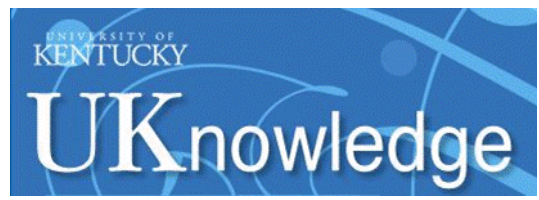

University of Kentucky

UKnowledge

Biosystems and Agricultural Engineering Faculty Publications

\title{
Effects of Sodium Hydroxide Pretreatment on Structural Components of Biomass
}

\author{
Alicia A. Modenbach \\ University of Kentucky, alicia.modenbach@uky.edu \\ Sue E. Nokes \\ University of Kentucky, sue.nokes@uky.edu
}

Follow this and additional works at: https://uknowledge.uky.edu/bae_facpub

Part of the Agriculture Commons, Bioresource and Agricultural Engineering Commons, Catalysis and Reaction Engineering Commons, Chemical Actions and Uses Commons, and the Polymer and Organic Materials Commons

Right click to open a feedback form in a new tab to let us know how this document benefits you.

\section{Repository Citation}

Modenbach, Alicia A. and Nokes, Sue E., "Effects of Sodium Hydroxide Pretreatment on Structural Components of Biomass" (2014). Biosystems and Agricultural Engineering Faculty Publications. 84. https://uknowledge.uky.edu/bae_facpub/84

This Article is brought to you for free and open access by the Biosystems and Agricultural Engineering at UKnowledge. It has been accepted for inclusion in Biosystems and Agricultural Engineering Faculty Publications by an authorized administrator of UKnowledge. For more information, please contact UKnowledge@lsv.uky.edu. 


\section{Effects of Sodium Hydroxide Pretreatment on Structural Components of Biomass}

Digital Object Identifier (DOI)

https://doi.org/10.13031/trans.57.10046

\section{Notes/Citation Information}

Published in Transactions of the ASABE, v. 57, issue 4, p. 1187-1198.

(C) 2014 American Society of Agricultural and Biological Engineers

The copyright holder has granted the permission for posting the article here. 


\section{EFFECTS OF SODIUM HYDROXIDE PRETREATMENT ON STRUCTURAL COMPONENTS OF BIOMASS}

\author{
A. A. Modenbach, S. E. Nokes
}

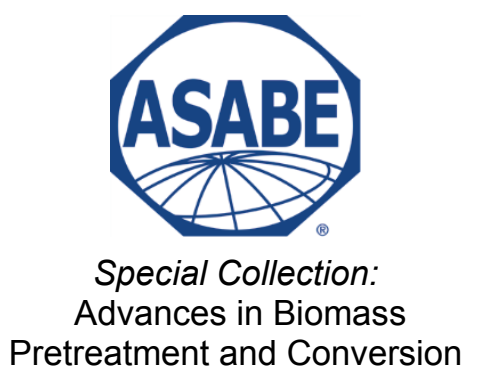

ABSTRACT. Pretreatment is a unit operation in the conversion of biomass to valuable products that utilizes various combinations of conditions, including chemicals, heat, pressure, and time, to reduce the recalcitrance of lignocellulose. Many such pretreatments have been developed over the years, as the operating conditions can be adapted so that lignocellulose is modified in ways unique to each pretreatment. By tailoring pretreatment conditions to achieve these modifications, the types of final products produced can be controlled. The purpose of this review is to provide a consolidated source of information for sodium hydroxide effects on lignocellulose. The structural characteristics of lignocellulose and the alterations that occur due to the application of sodium hydroxide are detailed. This review also includes a brief description of the chemical reaction mechanism that ensues during the pretreatment. Lastly, the results of studies that utilized sodium hydroxide pretreatment are discussed.

Keywords. Alkaline pretreatment, Cellulose, Lignin, Lignocellulose, Reaction mechanism, Sodium hydroxide.

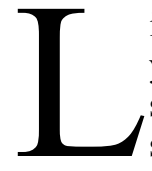

ignocellulose is the most abundant, renewable polymer present in nature. It has long been touted as a sustainable, environmentally friendly energy source; however, its recalcitrance has limited its use in an economically feasible manner. Alkaline pretreatment with sodium hydroxide is a viable, low-cost option for modifying the structure of lignocellulose prior to hydrolysis and fermentation of the carbohydrate fractions. It can be performed using a wide range of operating conditions (Hendriks and Zeeman, 2009; Modenbach and Nokes, 2012; Mosier et al., 2005). For instance, reaction times can be as short as a few minutes or on the order of hours or days, with temperature ranging from ambient to $150^{\circ} \mathrm{C}$ (Galbe and Zacchi, 2007; Jørgensen et al., 2007). Using sodium hydroxide for pretreatment is also advantageous over other pretreatments, such as dilute acid and ammonia fiber expansion (AFEX). The alkaline reagents are less caustic than dilute acid, and alkaline pretreatment can be performed at ambient pressure, unlike AFEX, eliminating the need for specialized equipment that is corrosion-resistant or that can withstand high pressures (Mosier et al., 2005). It is also possible to recover and recycle alkaline reagents, potentially reducing costs associated with pretreatment (Mosier et al., 2005).

Alkaline pretreatment can play an important role in the conversion of lignocellulose. With a narrow profit margin

Submitted for review in November 2012 as manuscript number FPE 10046 approved for publication by the Food \& Process Engineering Institute of ASABE in August 2013.

The authors are Alicia A. Modenbach, ASABE Member, Graduate Student, and Sue E. Nokes, ASABE Member, Professor, Department of Biosystems Engineering, University of Kentucky, Lexington, Kentucky. Corresponding author: Alicia Modenbach, 128 C.E. Barnhart Building, University of Kentucky, Lexington, KY 40546; phone: 859-257-3000; e-mail: alicia.modenbach@uky.edu. for commodity chemicals such as ethanol, it is imperative to develop a lignocellulose conversion process that can be integrated into a biorefinery concept. A biorefinery, modeled after the traditional petroleum refinery, should be capable of economically producing a variety of valuable and useful products, including liquid transportation fuels, commodity chemicals, and precursory chemical building blocks. Pretreatments using dilute acid and liquid hot water tend to remove the hemicellulose fraction, eliminating a potentially valuable energy stream. Xylose, the predominant carbohydrate found in hemicellulose of herbaceous biomass, can either be fermented by organisms capable of utilizing pentoses or converted into other chemical building blocks, such as xylitol and glycerol (Werpy and Peterson, 2004). Residual solids (such as lignin) produced from alkaline pretreatment can even be used to generate a number of other products. For example, lignin and/or its components can be used as a solid fuel source that can be burned to produce heat and electricity for the biorefinery or distributed to the grid for residential or commercial use (Jørgensen et al., 2007; Ragauskas et al., 2006); as a component of phenolic powder resins, polyurethane foams, epoxy resins, or biodispersants (Kadam et al., 2008; Lora and Glasser, 2002); or as valuable food and industrial products such as vanillin, ferulic acid, or vinyl guaiacol (Buranov and Mazza, 2008).

\section{STRUCTURE OF LigNOCELLULOSE}

Lignocellulose is composed of three main fractions: cellulose, hemicellulose, and lignin. Cellulose typically makes up the largest portion of these fractions at about $30 \%$ to $50 \%$ for herbaceous crops and about $40 \%$ to $50 \%$ for woody crops. Cellulose is a linear polymer, formed from $\beta$-1,4-linked glucose units (fig. 1a) and can contain up to 
15,000 of these monomers (O'Sullivan, 1997; Sticklen, 2007). The polymer chains bundle together into microfibrils. In its native form, cellulose is relatively recalcitrant, stabilized by the inter- and intra-strand hydrogen bonding and the resulting van der Waals forces (Chang, 2007; Zhang and Lynd, 2004). However, through use of pretreatment methods and cellulolytic enzymes, cellulose can be depolymerized into fermentable sugars.

Hemicellulose, another carbohydrate polymer that makes up about $20 \%$ to $30 \%$ of lignocellulose (Girio et al., 2010), is more randomly assembled and structurally more complex than cellulose (fig. 1b) since it can be composed of several different types of sugars compared to only glucose for cellulose. Hemicellulose is primarily comprised of xylan or glucomannan chains, intermixed with other components such as hexose (glucose, mannose, and galactose) and pentose (xylose and arabinose) sugars and uronic acids (glucuronic and galacturonic acids) (Hendriks and Zeeman, 2009). The variety and amount of each component is dependent on the lignocellulose source. For example, glucoronoxylans form a major portion of the hemicellulose in hardwoods, while galactoglucomannans account for a large portion of the hemicellulose in softwoods (Girio et al., 2010). Unlike cellulose, hemicellulose is a branched polymer (Moxley and Zhang, 2007; Sticklen, 2007). The hemicellulose often associated with agricultural residues (corn stover and wheat straw) contains branch points formed by arabinose and glucose chains substituted along the $\beta-1,4-$ linked xylose backbone. Cellulose is embedded within the hemicellulose matrix, which acts as a connection between the cellulose and lignin fractions and helps provide rigidity to the lignocellulose structure (Hendriks and Zeeman, 2009).

Lignin is a complex, phenolic polymer (fig. 2) that acts as a protective barrier encasing cellulose and hemicellulose. It also provides structural support for and transport of water within the plant (Buranov and Mazza, 2008; Grabber, 2005; Petridis et al., 2011). However, lignin becomes a major obstacle in the degradation of cellulose and hemicellulose, with its irregular linkages and non-repetitive order of components. The complexity of this polymer is due to three monolignol components, including $p$-coumaryl, coniferyl, and sinapyl alcohols and many of their derivatives, polymerizing into an irregular network via a number of different linkages ( $\beta-O-4$, $\alpha-O-4, \beta-5, \beta-1,5-5,4-0-5$, and $\beta-\beta$ linkages). Once integrated into the lignin polymer, these monolignols are referred to as $p$-hydroxyphenyl $(\mathrm{H})$, guaiacyl $(\mathrm{G})$, and syringyl (S) moieties, respectively (Buranov and Mazza, 2008; Grabber, 2005; Zhao et al., 2012). As with hemicellulose components, the ratio of H:G:S constituents of the lignin structure can vary depending on the source of the lignocellulose (Adler, 1977). For example, corn stover typically contains about $7 \%$ to $23 \%$ lignin (Cheng, 2010; Lee et al., 2007) that is comprised of H:G:S constituents in a ratio of 4:35:61 (table 1) (Grabber, 2005). However, softwoods are comprised of nearly $30 \%$ lignin and have a much different H:G:S ratio of 5:93.5:1.5 (Adler, 1977). Rice straw has a more balanced proportion of these units in terms of guaiacyl and syringyl moieties, with an H:G:S ratio of 15:45:40. Additionally, syringyl content has been linked to a plant's resistance to fungal infection (Buranov and Mazza, 2008). It is important to note that the combination of these constituents is not only critical to the structure of the plant, but also has implications for tailoring conversion process steps to achieve optimum product yield.

Lignin is attached to hemicellulose through a structure called the lignin-carbohydrate complex (LCC) (Buranov and Mazza, 2008; Grabber, 2005). In herbaceous biomass, the LCC is composed of a phenolic lignin unit linked to an arabinoxylan by ferulic acid (fig. 3), which reportedly varies from the type of LCCs present in woody biomass. Additionally, the location of the ferulic acid has shown slight differences depending on the lignocellulose source. For example, in wheat bran, the ferulic acid forms an ester linkage with the second carbon of an arabinose branch point off a xylan back bone, whereas the ester linkage occurs on the third carbon in

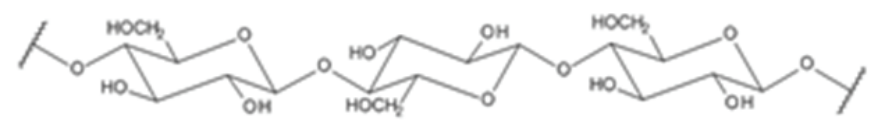

(a)

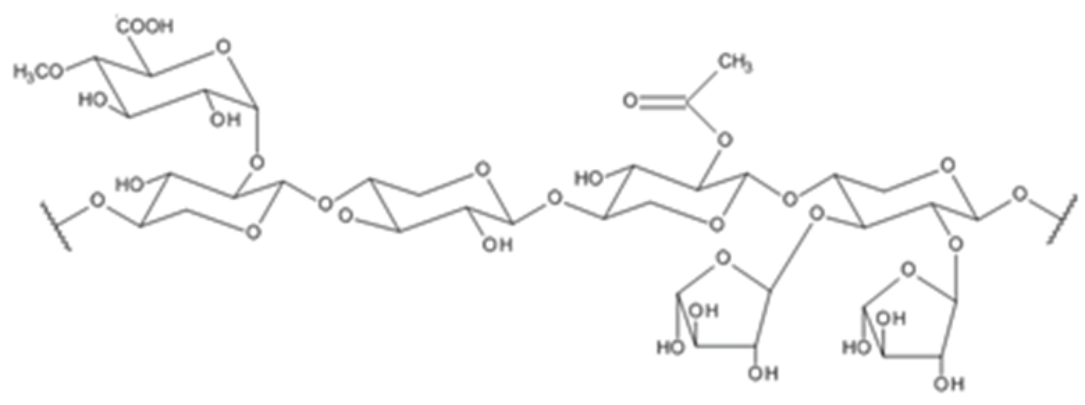

(b)

Figure 1. Chemical structures of (a) cellulose and (b) hemicellulose. The xylan backbone of hemicellulose contains various side chains and branch points, including glucose, arabinose, and acetate, making this carbohydrate chain more complex and variable than the linear cellulose chain. Figures adapted from Menon and Rao (2012). 


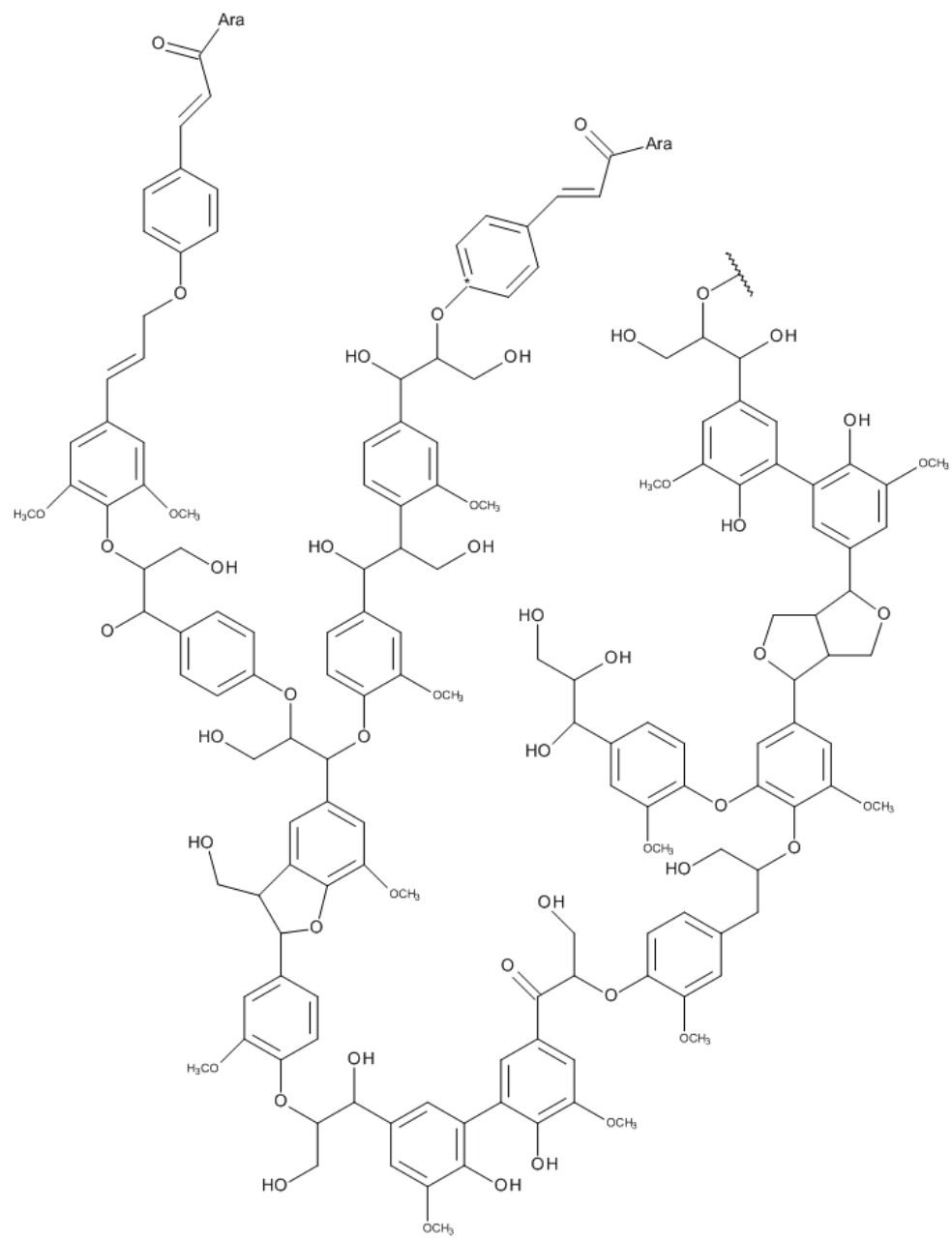

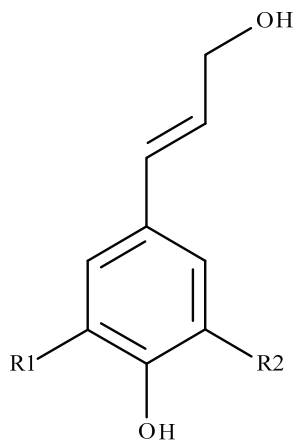

1. $\mathrm{R} 1=\mathrm{R} 2=\mathrm{H}$

2. $\mathrm{R} 1=\mathrm{OCH}_{3} ; \mathrm{R} 2=\mathrm{H}$

3. $\mathrm{R} 1=\mathrm{R} 2=\mathrm{OCH}_{3}$

Figure 2. Lignin (left) is a complex structure composed from three main monolignol components (right): (1) p-coumaryl, (2) coniferyl, and (3) sinapyl alcohols. Possible sites for linking lignin to hemicellulose are denoted by "Ara" (which represents arabinose). Figures adapted from Adler (1977) and Buranov and Mazza (2008).

bagasse and on the fifth carbon for grasses. It is believed that the ferulic acid acts as an anchoring point for the lignin into cell walls in the early stages of lignification and has a significant impact on a pretreatment's ability to hydrolyze the carbohydrate fractions (Wu et al., 2011). Grabber (2005) compared biomass with 4.5 and $15.9 \mathrm{~g} \mathrm{~kg}^{-1}$ ferulate cross-linkages and found that biomass with only $4.5 \mathrm{~g} \mathrm{~kg}^{-1}$ ferulate crosslinkages produced $46 \%$ and $20 \%$ more sugar after 6 and $72 \mathrm{~h}$ hydrolysis, respectively, indicating that the reduction in ferulate cross-linking significantly impacted both the initial rate and the extent of hydrolysis of the modified biomass.

Table 1. Typical ratios of lignin moieties found in various biomass sources. Ratios compiled from Buranov and Mazza (2008) and Lapierre et al. (1995).

\begin{tabular}{ccc}
\hline & Biomass & H:G:S \\
\hline Woody biomass & Poplar & $0: 37: 63$ \\
& Oak & $0: 32: 68$ \\
& Birch & $0: 22: 78$ \\
& Spruce & $2: 98: 0$ \\
& Pine & $18: 82: 0$ \\
\hline Herbaceous biomass & Corn & $4: 35: 61$ \\
& Wheat & $5: 49: 46$ \\
& Rice & $15: 45: 40$ \\
& Flax & $4: 67: 29$ \\
\hline
\end{tabular}

\section{MECHANISM OF SODIUM HYDROXIDE Pretreatment}

The ferulic acid linkage between the lignin and hemicellulose fractions is the point of reaction during $\mathrm{NaOH}$ pretreatment (Buranov and Mazza, 2008). The ester bond between the ferulic acid and the carbohydrate is highly susceptible to alkali degradation, as the hydroxide ion (dissociated from $\mathrm{NaOH}$ ) increases the rate at which the hydrolysis reaction occurs as compared to water (Bruice, 2004). The mechanism of alkaline pretreatment (fig. 4) is such that the hydroxide ion attacks the carbon of the ester bond (step 1), whether between the lignin and carbohydrate or even between two lignin components or two carbohydrate components. A tetrahedral intermediate forms (step 2) but quickly collapses when a negatively charged oxygen atom expels an alkoxide $\left(-\mathrm{OCH}_{3}\right)$ from the carboxylic acid (step 3). In a very fast reaction, the resulting alkoxide acts as a base, deprotonating the carboxylic acid (step 4). The result is the irreversible hydrolysis of the ester bond, weakening the structural integrity of the lignocellulose. 


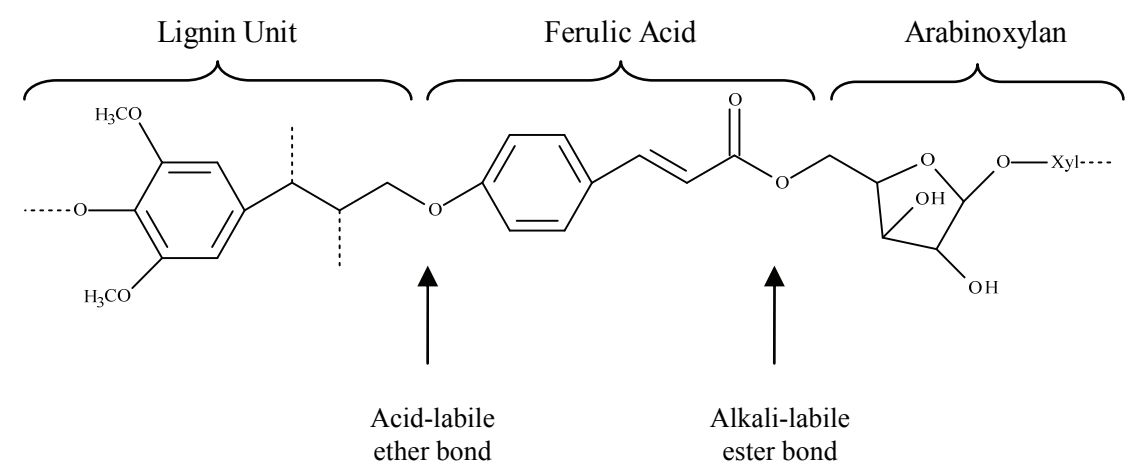

Figure 3. The lignin-carbohydrate complex. Ferulic acid links the phenolic lignin unit with an arabinoxylan chain. The resulting ether and ester bonds are susceptible to acid or alkali. Figure adapted from Buranov and Mazza (2008).
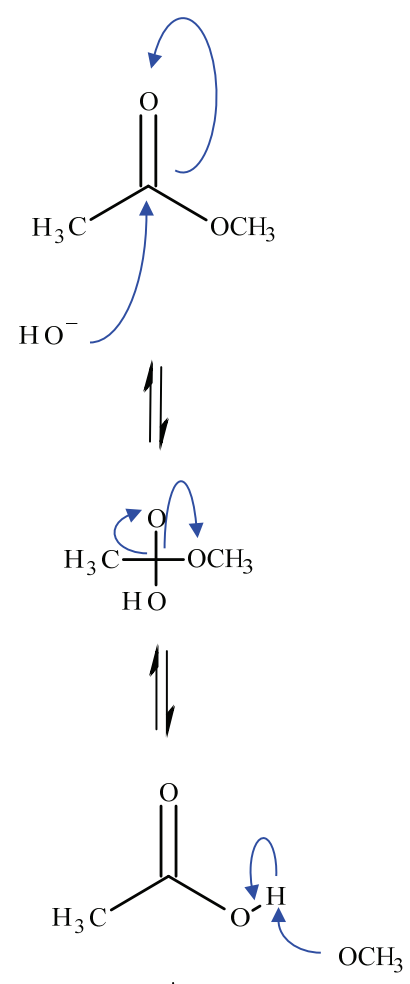

fast

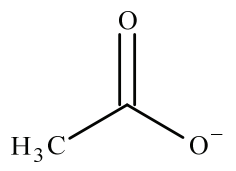

$\mathrm{HOCH}_{3}$

Figure 4. Mechanism of base hydrolysis of an ester bond. The hydroxide ion attacks the $\mathrm{C}$ of the $\mathrm{C}=\mathrm{O}$ bond. A tetrahedral intermediate forms but immediately collapses as an alkoxide leaves the carboxylic acid. In a very fast reaction, the alkoxide acts as a base and deprotonates the carboxylic acid. Arrows pointing from molecular components to other components or bonds indicate movement of electrons. Figure adapted from Carey (2000).

\section{StruCtural Changes AsSOCIATED WITH SODIUM HydRoXide PRETREATMENT}

Pretreatment with sodium hydroxide results in several structural modifications of lignocellulose that are beneficial for enzymatic hydrolysis. Bonds linking the protective lignin barrier with hemicellulose are broken. Depending on the pretreatment conditions, lignin is partially or totally solubilized, and degradation of the hemicellulose fraction may occur. Sodium hydroxide pretreatment also swells the lignocellulose particles, leading to an increase in surface area and greater accessibility to the cellulose fraction. Additionally, a decrease in the degree of polymerization and crystallinity of the cellulose is likely, increasing the enzymatic digestibility of the polysaccharide.

Solids loading of the system can also have significant impacts on the effectiveness of the pretreatment. At low solids loadings $(<10 \% \mathrm{w} / \mathrm{w}$ dry matter), where most conventional pretreatments have been developed, pretreatment processes have been shown to facilitate conversion of biomass into fermentable sugars (Modenbach and Nokes, 2012). However, these systems with higher water contents also require higher costs for handling and removing excess water and neutralizing the material prior to subsequent conversion steps. There is also the concern of treating a large effluent of wastewater, especially in instances where recycling and/or recovery of the pretreatment chemical are not possible. Some research has been conducted using $\mathrm{NaOH}$ pretreatment with higher solids loadings (Cheng et al., 2010; Cui et al., 2012) as a way to reduce the water requirements necessary during pretreatment. At high solids loadings ( $>15 \% \mathrm{w} / \mathrm{w}$ dry matter), many challenges that are not apparent with low solids loadings emerge. For instance, there may be little to no free water in the reactor, which could significantly impact the effectiveness of the pretreatment (Kristensen et al., 2009), since water aids in chemical reactions, reduces the viscosity of the slurry by increasing the lubricity of the particles, provides a medium for mass transfer by diffusion of the $\mathrm{NaOH}$ to the lignocellulose material, and improves the handling capability of the bulk material (Modenbach and Nokes, 2012). While it is not possible to give a definitive recommendation for the optimal moisture content during $\mathrm{NaOH}$ pretreatment without further study, it is possible to say that many factors must be considered when choosing pretreatment conditions 
in order to obtain an optimal sugar recovery and yield in subsequent processing steps.

\section{Structural Changes of Lignin}

Lignin is the main component of lignocellulose affected by $\mathrm{NaOH}$ pretreatment, and the pulp and paper industry has long taken advantage of alkaline delignification in the kraft process used in papermaking (Zhao et al., 2012). The kraft process uses $\mathrm{NaOH}$ at elevated temperatures $\left(160^{\circ} \mathrm{C}\right.$ to $170^{\circ} \mathrm{C}$ ) together with sodium sulfide to remove lignin and produce cellulose fibers from woody biomass (Hamaguchi et al., 2012; Wu et al., 2011). However, by-products of the kraft process, such as sulfur compounds and chlorinated compounds (Kadam et al., 2008), may have negative effects on other downstream processes in the conversion process. Additional processing to remove these compounds, as well as the wastewater treatment that would be required, can complicate pretreatment processes that directly mimic the kraft process. Sodium hydroxide alone is capable of removing lignin from lignocellulose of hardwood and herbaceous biomass, greatly simplifying the process. However, as alkaline pretreatment is developed for use prior to enzymatic hydrolysis in the conversion of lignocellulose into transportation fuels and other chemicals, researchers are more closely investigating the effects of alkaline pretreatment conditions on the delignification of biomass.

The alkaline pretreatment reacts with the ester bonds linking the lignin to the hemicellulose in the LCC network. As these bonds are broken, the LCC networking is disrupted, allowing lignin components to be solubilized. Duguid et al. (2009) saw $<2 \%$ reduction in lignin in corn stover when pretreated with $5.8 \mathrm{~g} \mathrm{NaOH}$ per $100 \mathrm{~g}$ biomass at room temperature for $2 \mathrm{~h}$, whereas Chen et al. (2009) observed $73.9 \%$ lignin removal in corn stover when pretreated with $16 \mathrm{~g} \mathrm{NaOH}$ per $100 \mathrm{~g}$ biomass at $121^{\circ} \mathrm{C}$ for $30 \mathrm{~min}$ (table 2). Alkaline pretreatment can also cause xylan solubilization, especially where xylan is associated with the LCC complex (Cui et al., 2012). For instance, Cui et al. (2012) reported up to $34 \%$ loss of xylan coupled with 22\% lignin degradation during pretreatment with $5 \mathrm{~g} \mathrm{NaOH}$ per $100 \mathrm{~g}$ biomass and $75 \%$ moisture content for 90 days. It has been hypothesized that disruption of this cross-linking enhances enzyme adsorption and enzyme effectiveness by reducing inhibition of xylooligomers and unproductive binding with lignin (Kim and Holtzapple, 2006; Kumar et al., 2009; Wu et al., 2011). Removal of lignin by $\mathrm{NaOH}$ often leads to the release of acetyl groups and uronic acid substitutions, which can enhance the digestibility of cellulose and hemicellulose (Cui et al., 2012; Kumar et al., 2009; Wan et al., 2011). However, hydrolytic enzymes can be inhibited by some of these degradation products, such as xylooligomers (Qing et al., 2010), organic acids, phenols (Kim et al., 2011), furfural, and hydroxymethyl furfural (HMF) (Hodge et al., 2008), making the selection of process conditions, including alkaline loading, moisture content, temperature, and time, extremely important. Balance is the key to achieving optimal lignin removal while limiting the production of inhibitory compounds. For instance, Cui et al. (2012) found that delignification was influenced by $\mathrm{NaOH}$ loading, time, and moisture content during long-term wet storage of corn stover. Addition of 2 to $5 \mathrm{~g} \mathrm{NaOH}$ per $100 \mathrm{~g}$ biomass increased lignin degradation by $\sim 10 \%$ to $25 \%$ over a 90-day storage period; however, most of this lignin degradation occurred within the first five days of storage. A higher loss in xylan (up to 34\%) was also observed with the increase in lignin degradation. Wan et al. (2011) also observed a sharp increase in xylan degradation with an increase in lignin degradation. As $\mathrm{NaOH}$ loading increased from $4 \mathrm{~g}$ to $40 \mathrm{~g} \mathrm{NaOH}$ per $100 \mathrm{~g}$ biomass, lignin degradation increased moderately from $\sim 7 \%$ to $\sim 15 \%$, but xylan removal increased from $5 \%$ to nearly $50 \%$ over the same $\mathrm{NaOH}$ loadings. Although no inhibition was observed during enzymatic hydrolysis, and inhibitor concentrations were not measured, the presence of inhibitory compounds from the degradation of xylan is possible. However, they were likely removed during the washing and neutralizing of the soybean straw prior to use in the hydrolysis reaction.

As mentioned previously, lignin structures vary with different sources of lignocellulose, which means that $\mathrm{NaOH}$ pretreatment works more effectively on some sources of biomass than others. Shimizu et al. (2012) investigated the effects of $\mathrm{NaOH}$ on the degradation of the $\beta-\mathrm{O}-4$ bonds between model lignin dimers. They reacted guaiacylguaiacyl (G-G), guaiacyl-syringyl (G-S), syringyl-guaiacyl (S-G), and syringyl-syringyl (S-S) dimers with a $1 \mathrm{M}$ $\mathrm{NaOH}$ solution at $40^{\circ} \mathrm{C}$ to $70^{\circ} \mathrm{C}$ for 3 to $7 \mathrm{~h}$ and found that the compounds containing a syringyl unit reacted more readily in the alkaline solution as compared to G-G dimers. The orientation of the dimer components also affected the rate of degradation, as the S-G and G-S dimers did not degrade at an equivalent rate. The order of the rates of degradation was determined as follows: $\mathrm{S}-\mathrm{S}>\mathrm{G}-\mathrm{S}>\mathrm{S}-\mathrm{G}>\mathrm{G}-\mathrm{G}$, where S-S degraded nearly 7.5-fold faster than G-G at $130^{\circ} \mathrm{C}$. As with these model lignin compounds, real sources of lignocellulose containing a higher proportion of syringyl units are more easily delignified. Lignin from hardwoods is composed of $\sim 7$ to 40 times more syringyl units than lignin from softwoods (Adler, 1977), making hardwoods more susceptible to alkaline pretreatment than softwoods (Shimizu et al., 2012). Rice straw, bagasse, and some grasses, which tend to have S-G ratios more similar to hardwoods than to softwoods, have shown significant lignin removal following alkaline $(\mathrm{NaOH})$ pretreatment at short reaction times and moderate temperatures (data not given) ( $\mathrm{Wu}$ et al., 2011). These sources of lignocellulose also contain high levels of syringyl units $(10 \%$ to $65 \%)$ in the lignin fraction (Adler, 1977).

\section{Degradation of Cellulose}

Alkaline degradation of cellulose is dependent on several factors, including the nature and concentration of the alkali, the nature and origin of the cellulose, and temperature (Ciolacu and Popa, 2005; Fengel et al., 1995; Knill and Kennedy, 2003). At relatively low temperatures $\left(<100^{\circ} \mathrm{C}\right)$ and low alkali concentrations $(<4 \%)$, structural changes for cellulose are insignificant, as glycosidic $\beta(1,4)$ linkages are alkali-stable under these conditions (Knill and Kennedy, 2003). Kim and Holtzapple (2006) reported no significant structural changes or degradation to cellulose after pretreatment with $50 \mathrm{~g} \mathrm{Ca}(\mathrm{OH})_{2}$ per $100 \mathrm{~g}$ biomass at low 
Table 2. Effects of pretreatment conditions on biomass composition and enzymatic hydrolysis of cellulose to glucose.

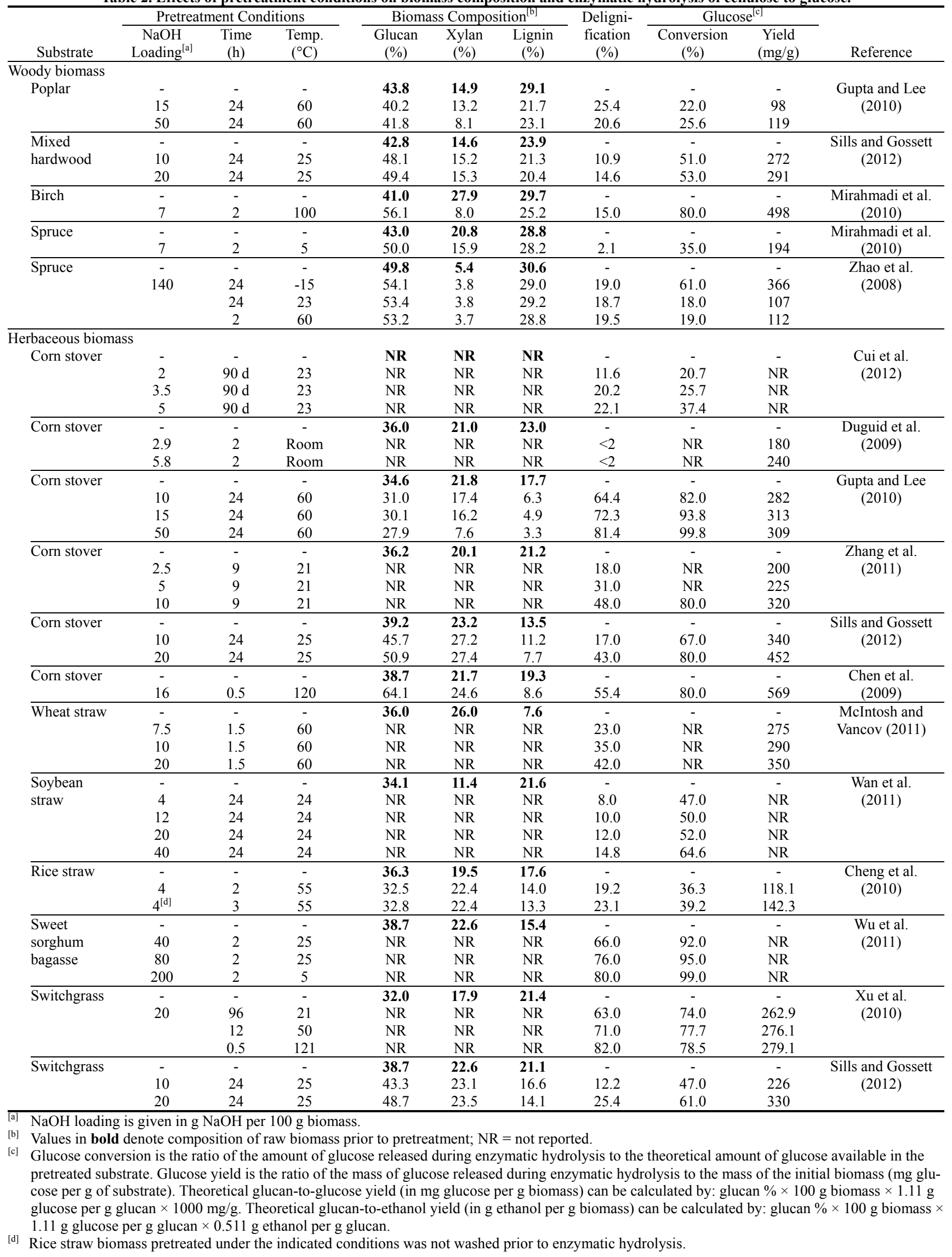


temperatures $\left(25^{\circ} \mathrm{C}\right.$ to $\left.55^{\circ} \mathrm{C}\right)$, even for extended pretreatment times up to 16 weeks. Another study (Cui et al., 2012) reported that long-term storage (90 days) of wet corn stover without the addition of $\mathrm{NaOH}$ resulted in $\sim 10 \%$ loss of cellulose; however, storage with the application of $2 \mathrm{~g}$ $\mathrm{NaOH}$ per $100 \mathrm{~g}$ biomass caused only $\sim 5 \%$ degradation of cellulose. The addition of $\mathrm{NaOH}$ likely made the environmental conditions unfavorable for microorganisms that would have grown on the cellulose, thus protecting it from microbial degradation. These conditions (low alkali concentrations and low to moderate temperatures) are favorable for lignocellulose pretreatment because lignin is affected, but most of the cellulose remains unaltered and available for hydrolysis into fermentable carbohydrates.

At higher alkali concentrations $(>6 \%)$, many structural and morphological changes begin to occur in cellulose. As alkali concentrations increase, crystallite structures (regions of highly ordered polymer chains interspersed with more amorphous regions) begin to swell. The swelling starts first in amorphous regions, followed by the crystalline region. The degree of polymerization (DP) and the degree of crystallinity (CrI; crystallinity index) decrease with increasing alkali concentration (Eronen et al., 2009; Mittal et al., 2011). Ciolacu and Popa (2005) studied the structural changes of microcrystalline cellulose, cellulose linters (secondary growth of short, thick-walled fibers produced by cotton), and spruce pulp treated with several alkali concentrations $(0 \%$ to $18 \% \mathrm{NaOH})$. At $18 \% \mathrm{NaOH}$, they observed similar reductions $(\sim 19 \%)$ in both the DP and $\mathrm{CrI}$ for microcrystalline cellulose and cellulose linters as compared to treatment without the addition of alkali, whereas the DP and CrI of spruce pulp were reduced by $27 \%$ and $36 \%$, respectively. These structural changes are advantageous for the conversion of lignocellulose into fermentable sugars because enzymatic hydrolysis is enhanced as amorphous regions of cellulose are more easily digested by cellulolytic enzymes.

Additionally, increased alkali concentrations can lead to partial or total transformation of cellulose I to cellulose II through a process known as mercerization (Ciolacu and Popa, 2005; Eronen et al., 2009). Cellulose I is natural cellulose produced by bacteria, algae, and higher-order plants in which the cellulose chains are parallel to one another (fig. 5). Cellulose II is a form of regenerated cellulose in which the chains lie antiparallel to one another (O'Sullivan, 1997). This transformation begins at $\mathrm{NaOH}$ concentrations of about $7.5 \%$ to $10 \%$ and $10 \%$ to $12.5 \%$ for spruce pulp and cotton linters, respectively (Ciolacu and Popa, 2005). At these concentrations, the cellulose lattice swells as intermolecular hydrogen bonds are broken and chain conformations are altered, resulting in amorphous regions. Cleavage of intramolecular hydrogen bonds further degrades the structural regularity of the crystalline regions of cellulose, subsequently reducing the DP and the crystallinity of the cellulose. Eronen et al. (2009) used Raman spectroscopy to show the structural changes that resulted from breaking these hydrogen bonds. They also reported that AFM imaging revealed that cellulose II appeared to be more granular as compared to cellulose I, indicating that transformation from cellulose I to cellulose II not only changes the chemical structure but also the physical appearance of the cellulose.

The nature and origin of the cellulose play a significant role in the structural changes caused by alkaline treatment, as evidenced by the differences in reduction of DP and CrI in pure cellulose substrates (microcrystalline cellulose and cellulose linters) as compared to lignocellulose (spruce pulp) substrates discussed previously. Additionally, Ishikura et al. (2010) reported longitudinal contraction and changes in mechanical properties of wood; however, lattice transformations typical of alkali-treated cotton fibers were not observed. It was hypothesized that the lignin matrix likely prevented sufficient swelling of the cellulose fibers and crystallites that leads to lattice transformations. However, some pockets of swelling occurred and resulted in regions of amorphous cellulose where crystalline cellulose was previously, since the fibers could not return to the crys-

(a)

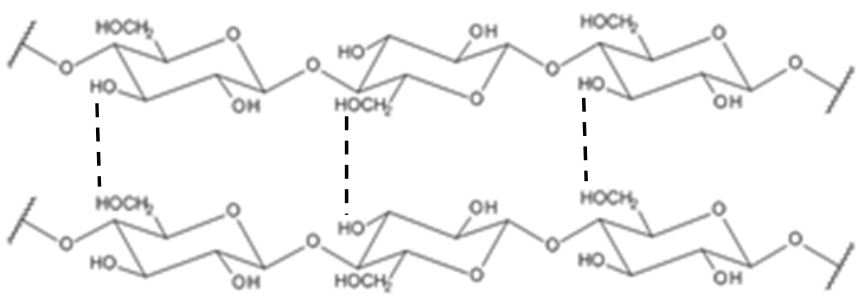

(b)

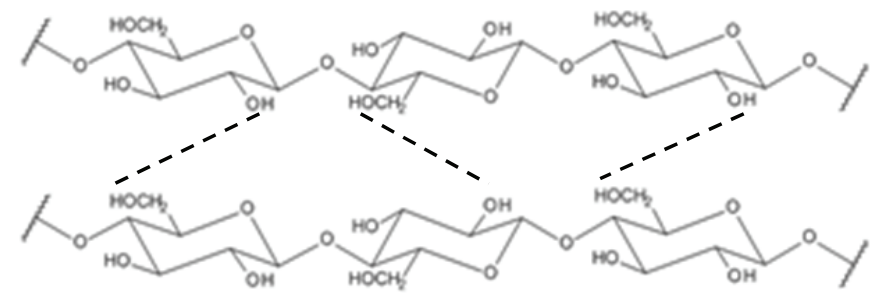

Figure 5. Schematic of two cellulose polymorphs: (a) cellulose I and (b) cellulose II. The dotted lines indicate possible hydrogen bonds between neighboring strands of cellulose. 
talline structure upon removal of the $\mathrm{NaOH}$. Degradation of cellulose treated with $\mathrm{NaOH}$ is also dependent on the initial DP of the cellulose. Mittal et al. (2011) reported that cellulose sources with greater initial DP were not solubilized as readily as cellulose sources with lower initial DP. For example, Avicel, which had a lower DP ( 90$)$ than the other cellulose sources investigated, released nearly $20 \%$ of its cellulose when treated with $1926 \mathrm{~g} \mathrm{NaOH}$ per 100 g cellulose at $25^{\circ} \mathrm{C}$ for $2 \mathrm{~h}$. Cellulose was more easily solubilized for Avicel fractions with a DP of $<40$. Conversely, cotton linters, which had an initial DP of 600, experienced very little cellulose solubilization during the $\mathrm{NaOH}$ treatment. Comparatively, the DP of corn stover is reported to be $\sim 7,000$, much higher than other sources of pure cellulose (Kumar et al., 2009).

The temperature at which the alkaline treatment of cellulose is conducted can also cause significant changes to the structure. Low to moderate temperatures $\left(<100^{\circ} \mathrm{C}\right)$ are preferential for alkaline pretreatment prior to the conversion of lignocellulose to fermentable sugars, since cellulose is affected very little at these temperatures, as mentioned earlier. However, at higher temperatures $\left(>100^{\circ} \mathrm{C}\right)$, cellulose is more likely to undergo significant degradation and structural changes. Boiling cellulose in a $\mathrm{NaOH}$ solution can lead to a reaction known as "peeling" or "unzipping," in which the reducing ends of the cellulose chain are subjected to $\beta$-alkoxy-carbonyl elimination. The resulting products are a glucoisosaccharinic acid and another reducing end that propagates the peeling reaction (Knill and Kennedy, 2003; Machell et al., 1957), with an average of nearly 50 glucose molecules removed before termination occurs (Whistler and Bemiller, 1958). However, some reducing ends may remain stable if they are inaccessible to the alkali due to the nature of the cellulose, leading to the termination of further degradation. At even higher temperatures $\left(>170^{\circ} \mathrm{C}\right)$, hydrolysis or alkaline scission can occur at random locations along the cellulose chain (Knill and Kennedy, 2003). This hydrolysis can lead to new reducing ends that are vulnerable to degradation. Peeling, termination, and scission tend to occur in anaerobic conditions; however, under oxidized conditions, carbonyl groups are often hydrolyzed. More specifically, carbonyl groups located at any position along the cellulose chain (except those positioned as an end group) are extremely alkali-labile even under mild conditions, and nearly all cellulose molecules containing these carbonyl groups are hydrolyzed (Knill and Kennedy, 2003), indicating that alkaline pretreatment may be more effective in an oxidative environment.

\section{Changes to Hemicellulose}

Hemicellulose, with its branched and somewhat irregular structure, tends to be the most sensitive of the three lignocellulose fractions to changes in pretreatment conditions (Chandra et al., 2007). In dilute alkaline pretreatment conditions, hemicellulose remains mostly intact with the cellulose fraction (Chandra et al., 2007; Varga et al., 2002); however, some studies have shown that hemicellulose can be solubilized as $\mathrm{NaOH}$ concentrations increase. For exam- ple, both Varga et al. (2002) and Li et al. (2004) found that hemicellulose content in the solid fraction was reduced by more than $60 \%$ when pretreating lignocellulose with $10 \%$ $\mathrm{NaOH}$. Solubilization of hemicellulose in these more severe pretreatment conditions can also lead to further degradation of sugars into furfural and HMF, two components known for their inhibitory effects on fermentation (Chandra et al., 2007). Additional changes occurring during the alkaline pretreatment of lignocellulose that have been noted include saponification of the ester bonds that link hemicellulose to other lignocellulosic components, removal of acetyl and uronic acid substitutions on hemicellulose, and the formation of salts both in solution and incorporated into the lignocellulose (Carvalheiro et al., 2008).

\section{LIMITATIONS OF SODIUM HYDROXIDE in Pretreatment}

Currently, pretreatments are typically chosen in such a way as to limit inhibitor production while optimizing glucose retention for subsequent processing steps. Even though progress has been made through supplementing cellulases with xylanases during enzymatic hydrolysis and genetically modifying fermentation organisms, glucose is still the favored feedstock of existing fermentation technology. One limitation of sodium hydroxide pretreatment is that in mild operating conditions, this pretreatment requires long reaction times, usually on the order of hours or days (Balat et al., 2008). In addition, cellulose and hemicellulose are left relatively intact, while only the lignin is modified (Chandra et al., 2007). Not only can hemicellulose act as a barrier if left in the solid fraction with cellulose, but any portions that are solubilized during pretreatment can act as inhibitors to the cellulase enzymes used in enzymatic hydrolysis (Qing et al., 2010). However, other pretreatments, such as dilute acid and liquid hot water, simply solubilize the hemicellulose fraction and discard it with the waste stream, essentially eliminating a large portion of potential energy. If harsher conditions are used to remove more of the hemicellulose in $\mathrm{NaOH}$ pretreatment, then not only does the potential carbohydrate yield decrease, but solubilized hemicellulose components can be degraded further into furan derivatives and their acids (furfural, HMF, formic acid, and levulinic acid), which are inhibitory to fermentative organisms at concentrations as low as $1 \mathrm{~g} \mathrm{~L}^{-1}$ (Cantarella et al., 2004). Since the main mechanism of this pretreatment is delignification of biomass, it is most effective on herbaceous biomass. Woody biomass or biomass high in lignin reduces the usefulness of $\mathrm{NaOH}$ pretreatment (Balat et al., 2008; Galbe and Zacchi, 2007). Additionally, lignin may not be completely solubilized but simply redistributed and condensed onto the cellulose, eliminating any positive effects from structural changes associated with lignin removal and swelling of the biomass (Hendriks and Zeeman, 2009). Lastly, not all of the $\mathrm{NaOH}$ can be recovered and recycled, as in alkaline pretreatment with lime. Some of the $\mathrm{NaOH}$ is consumed during the pretreatment, being incorporated into the biomass as salts (Balat et al., 2008; Carvalheiro et al., 2008; Mosier et al., 2005). 


\section{USE OF SODIUM HYDROXIDE in Pretreatment}

Sodium hydroxide has received much attention lately as a potential pretreatment option because it is inexpensive, effective on a variety of feedstocks, and less energy intensive as compared to other pretreatment options ( $\mathrm{Xu}$ et al., 2010). While much research has been conducted on the use of sodium hydroxide as a pretreatment agent, further study is still warranted to fully understand the mechanisms associated with it and optimize the carbohydrate recovery and yields for use in fermentation. A brief review of a few selective studies highlighting the progress that has been made but also indicative of the work necessary to improve the process is included here.

An early study by Macdonald et al. (1983) investigated the effects of alkaline pretreatment at low $\mathrm{NaOH}$ concentrations ( 0 to $32 \mathrm{~g} \mathrm{NaOH}$ per $100 \mathrm{~g}$ biomass) and elevated temperatures $\left(100^{\circ} \mathrm{C}\right.$ to $\left.150^{\circ} \mathrm{C}\right)$ on corn stover, with residence times ranging from 1 to $60 \mathrm{~min}$. The lignin and hemicellulose fractions were partially solubilized under the conditions studied, and the extent of solubilization was found to be dependent on the combination of reaction conditions (time, temperature, and $\mathrm{NaOH}$ concentration). Cellulose was relatively unaffected by the pretreatment, and most was recovered prior to enzymatic hydrolysis. These results are consistent with other studies that have reported solubilization of the lignin and hemicellulose fractions occurring at low alkaline concentrations and high temperatures, while cellulose remained mostly unaffected (Mirahmadi et al., 2010). Additionally, the authors reported that nearly $85 \%$ of the solubilization that took place at $120^{\circ} \mathrm{C}$ and for various $\mathrm{NaOH}$ concentrations occurred within the first minute of the pretreatment, after which the rate slowed significantly over the next 20 to $30 \mathrm{~min}$ (Macdonald et al., 1983). This study further highlights the effects that reaction conditions have on the lignocellulose, both individually and in combination. For example, the extent of solubilization appeared to be proportional with the $\mathrm{NaOH}$ concentration, as solubilization increased with increasing $\mathrm{NaOH}$ concentration up to $16 \mathrm{~g} \mathrm{NaOH}$ per $100 \mathrm{~g}$ biomass. However, pretreatment at higher $\mathrm{NaOH}$ concentrations did not increase the amount of material removed from the corn stover. In fact, the higher $\mathrm{NaOH}$ concentration may have had detrimental effects on the components of lignocellulose, including loss of cellulose and degradation of solubilized hemicellulose and lignin into inhibitory products. Composition measurements showed that pretreatment performed with $\mathrm{NaOH}$ loadings of $16 \mathrm{~g} \mathrm{NaOH}$ per $100 \mathrm{~g}$ biomass increased cellulose content from $32 \%$ to $70 \%$, which was the maximum cellulose content observed under the conditions investigated, by removing other components such as hemicellulose and lignin from the lignocellulose. Removal of these other components essentially reduced the mass of the total material as opposed to increasing the mass of the cellulose, which resulted in the increased percent cellulose content. Cellulose content was only increased to $41 \%$ when treated in the absence of $\mathrm{NaOH}$. This study also reported that a change in pretreatment temperature from $100^{\circ} \mathrm{C}$ to $140^{\circ} \mathrm{C}$ produced the largest change in solubility of the hemicellu- lose and lignin components, whereas the change in solubility for temperatures $>140^{\circ} \mathrm{C}$ were insignificant. Additional findings suggest that pretreatment temperature played a significant role in the enzymatic digestibility of lignocellulose. Following enzymatic hydrolysis (performed at $40^{\circ} \mathrm{C}$ for $48 \mathrm{~h}$ with an enzyme loading of $1.5 \%$ and a substrate loading of 5\% w.b.) of lignocellulose pretreated with $32 \mathrm{~g}$ $\mathrm{NaOH}$ per $100 \mathrm{~g}$ biomass for 15 min, sugar yields were higher when the pretreatment was performed at $150^{\circ} \mathrm{C}$ than at $120^{\circ} \mathrm{C}$, yielding $77.5 \%$ sugars as compared to $67.1 \%$ sugars, respectively. Development and optimization of pretreatment processes rely on striking a balance between the various reaction conditions. Temperature, time, and alkaline concentration should be chosen in conjunction with the lignocellulose source to obtain the optimal sugar recovery and produce the maximum sugar yields possible.

$\mathrm{Xu}$ et al. (2010) investigated the use of $\mathrm{NaOH}$ pretreatment on another herbaceous lignocellulose source. Switchgrass (SG) was pretreated at high $\left(121^{\circ} \mathrm{C}\right)$, moderate $\left(50^{\circ} \mathrm{C}\right)$, and low $\left(21^{\circ} \mathrm{C}\right)$ temperatures with $\mathrm{NaOH}(5$ to $20 \mathrm{~g}$ $\mathrm{NaOH}$ per $100 \mathrm{~g}$ biomass) for up to $96 \mathrm{~h}$. Raw switchgrass was composed of $32 \%$ glucan, $18 \%$ xylan, and $21 \%$ lignin, with the remainder being ash, minor sugars, and other unquantified components. At the high temperature, the results of this study were similar to those achieved in the study previously discussed (Macdonald et al., 1983). For switchgrass pretreated at $121^{\circ} \mathrm{C}$ with $10 \mathrm{~g} \mathrm{NaOH}$ per $100 \mathrm{~g}$ biomass solution for $0.5 \mathrm{~h}$, enzymatic hydrolysis produced $42.5 \mathrm{~g}$ total reducing sugar per $100 \mathrm{~g} \mathrm{SG}$ (which included $28 \mathrm{~g}$ glucose per $100 \mathrm{~g} \mathrm{SG}$ ). Lower temperatures are of interest because they would lower heating requirements and possibly reduce energy inputs, although longer residence times may be necessary to achieve the same degree of solubilization. Maximum glucose yield was similar for samples pretreated with a $\mathrm{NaOH}$ loading of $20 \mathrm{~g} \mathrm{NaOH}$ per $100 \mathrm{~g}$ biomass at either $50^{\circ} \mathrm{C}$ or $121^{\circ} \mathrm{C}(27.6 \mathrm{~g}$ or $27.9 \mathrm{~g}$ glucose per $100 \mathrm{~g} \mathrm{SG}$, respectively). However, the lower temperature required a much longer residence time to reach this yield: $12 \mathrm{~h}$ instead of $0.5 \mathrm{~h}$. Additionally, the lower reaction temperature reduced the amount of hemicellulose solubilized during pretreatment, meaning that it was available during the enzymatic hydrolysis step, which increased the final total reducing sugar yield. Hydrolysis of switchgrass pretreated at $50^{\circ} \mathrm{C}$ resulted in $7 \%$ higher total reducing sugar yields as compared to switchgrass pretreated at $121^{\circ} \mathrm{C}$ (45.3 g vs. $42.5 \mathrm{~g}$ total reducing sugar per $100 \mathrm{~g} \mathrm{SG}$, respectively). Reducing the temperature even further, however, to $21^{\circ} \mathrm{C}$ did not result in a higher total reducing sugar yield. In fact, the maximum total reducing sugar yield produced at $21{ }^{\circ} \mathrm{C}$ was $5 \%$ and $10 \%$ lower than the yields observed at the high and moderate temperatures, respectively, indicating that it may be more cost effective to not heat the pretreatment reaction and sacrifice the additional yield. Conversely, a $5 \%$ to $10 \%$ reduction in yield may look small at the laboratory scale; however, once the process is scaled up for a biorefinery, a $5 \%$ to $10 \%$ reduction in yield is much more significant when dealing with large amounts of material. A full techno-economic analysis of this process would be required before a decision on operating conditions could be made. This study again illustrates the im- 
portance of striking a balance between the pretreatment reaction conditions that remove the most non-carbohydrate components as possible while still achieving the highest sugar yields possible. The most severe pretreatment is not always the best option. For example, solid recovery decreased with increasing pretreatment severity, with as much as $54 \%$ of the switchgrass being lost during the most severe pretreatment $\left(121^{\circ} \mathrm{C}, 20 \mathrm{~g} \mathrm{NaOH}\right.$ per $100 \mathrm{~g}$ biomass, $1 \mathrm{~h}$ ). Maximum lignin reduction was also observed under these conditions; however, removal of lignin may not be the best indicator of pretreatment effectiveness, especially if less of the carbohydrate fraction is recovered following pretreatment.

The use of sodium hydroxide as a pretreatment is more prevalent with herbaceous biomass than with woody biomass. However, researchers have not been deterred from investigating combinations of potential reaction conditions, especially since soda pulping, which is in part an alkaline treatment, has long been established by the pulp and paper industry. Mirahmadi et al. (2010) pretreated birch (a hardwood) and spruce (a softwood) at various temperatures from $-15^{\circ} \mathrm{C}$ to $100^{\circ} \mathrm{C}$ with $7 \mathrm{~g} \mathrm{NaOH}$ per $100 \mathrm{~g}$ biomass for $2 \mathrm{~h}$. At concentrations above $6 \mathrm{~g} \mathrm{NaOH}$ per $100 \mathrm{~g}$ biomass, sodium hydroxide can be used at lower temperatures and atmospheric pressure and still maintain its effectiveness as a pretreatment agent. However, with woody biomass, lignin is not significantly removed and cellulose begins to degrade. Reduced lignin removal is likely due to the difference in ratios of the lignin structural components found in woody biomass. In this study, some lignin was removed from birch ( $\sim 5 \%$ to $16 \%$ as compared to untreated birch), whereas very little lignin was solubilized from the spruce samples $(<5 \%$ as compared to untreated spruce). Higher pretreatment temperatures led to higher loss of the hemicellulose fraction, which was also evidenced in other studies (Macdonald et al., 1983; Xu et al., 2010). Breaking the ester bonds between the lignin and hemicellulose fractions increases the porosity, and therefore the surface area, of the lignocellulose but at the expense of partially degrading the hemicellulose and cellulose fractions. Cellulose content subsequently improved following pretreatment due to the loss of lignin and hemicellulose. Birch showed the greatest changes in structure following pretreatment compared to spruce. Cellulose content of birch increased by $37 \%$ because of the removal of lignin and hemicellulose components. Additionally, the crystallinity of the cellulose was reduced by $23 \%$ after pretreatment at $100^{\circ} \mathrm{C}$. In comparison, the cellulose content of spruce was increased by only $22 \%$, and the cellulose crystallinity was relatively unchanged, starting at 0.68 for untreated spruce and reducing to only 0.63 to 0.65 for all conditions tested. Cellulose was likely not as affected in the spruce samples due to the insignificant amount of lignin removed. The lack of a major effect on the spruce material is not surprising, since it is a softwood species and $\mathrm{NaOH}$ pretreatment is not as effective on softwood as it is on hardwoods and herbaceous materials. The structural changes afforded by the pretreatment improved the accessibility of the cellulose to enzymatic degradation, as can be seen by the increased yields following hydrolysis. Glucose yields from birch samples pretreat- ed at $100^{\circ} \mathrm{C}$ reached nearly $80 \%$, whereas the maximum glucose yield produced by spruce samples was $35 \%$ for material pretreated at $5^{\circ} \mathrm{C}$. It should be noted that these are also the same respective pretreatment conditions that achieved maximum reduction in crystallinity of cellulose, which further illustrates the importance of certain structural changes produced through pretreatment.

Softwood lignocellulose is the most difficult material to hydrolyze, mainly because it typically contains up to $30 \%$ lignin (Cheng, 2010) but also because the lignin is composed of $>90 \%$ guaiacyl units, which are not easily hydrolyzed by sodium hydroxide (Shimizu et al., 2012). Another study using the softwood spruce found that extremely low pretreatment temperatures $\left(<0^{\circ} \mathrm{C}\right)$ were successful at removing lignin and hemicellulose, as well as disrupting the bonds between these fractions and modifying the lignocellulose structure, making cellulose more accessible (Zhao et al., 2008). However, some cellulose was also lost during pretreatment performed at freezing temperatures, although the loss of cellulose was comparable to pretreatments performed at ambient and higher temperatures investigated in this study. Both low (20 to $60 \mathrm{~g} \mathrm{NaOH}$ per $100 \mathrm{~g}$ biomass) and high (140 to $240 \mathrm{~g} \mathrm{NaOH}$ per g biomass) concentrations of sodium hydroxide were investigated at $-15^{\circ} \mathrm{C}$, $23^{\circ} \mathrm{C}$, and $60^{\circ} \mathrm{C}$. The pretreatment time for the two former temperatures was $24 \mathrm{~h}$, while the latter was $2 \mathrm{~h}$ in order to limit the amount of carbohydrate degradation that occurred at the higher temperature for extended periods of time. At the higher $\mathrm{NaOH}$ concentrations, glucose yield exceeded $60 \%$ for the material pretreated at $-15^{\circ} \mathrm{C}$, which represents the maximum yields observed in this study. Comparatively, these yields are more than three times greater than those achieved for material pretreated with $140 \mathrm{~g} \mathrm{NaOH}$ per $100 \mathrm{~g}$ biomass at $23^{\circ} \mathrm{C}$ and $60^{\circ} \mathrm{C}$, which yielded $18 \%$ and $20 \%$, respectively. However, the composition of the spruce following pretreatment at $140 \mathrm{~g} \mathrm{NaOH}$ per $100 \mathrm{~g}$ biomass was not significantly different for the three temperatures. Lignin, hemicellulose, and cellulose were reduced by approximately $19 \%, 40 \%$, and $8 \%$, respectively, for each of the three pretreatments. Based on the hydrolysis conversions, it is likely that the use of freezing temperatures may do more than remove the lignin and hemicellulose and may positively affect the structural characteristics of the spruce. One hypothesis is that freezing water may increase pore size, thereby increasing the effective surface area, making the cellulose more accessible to enzymatic degradation. However, the energy required to maintain a $-15^{\circ} \mathrm{C}$ environment for pretreatment would be high and likely not feasible on a large scale. A techno-economic analysis would be necessary to determine whether the improvement in glucose yield from softwoods justifies the higher energy input for $\mathrm{NaOH}$ pretreatment.

\section{CONCLUSION}

Different combinations of pretreatment conditions affect lignocellulose in distinct ways, opening up opportunities to tailor the process to produce a variety of desired products. Temperature, duration of pretreatment, and reagent concen- 
tration all play significant roles in altering the structure of lignocellulose and improve accessibility of cellulose for enzymatic hydrolysis. Sodium hydroxide has been shown to solubilize lignin and some hemicellulose by breaking the ester bonds of the lignin-carbohydrate complex (LCC) that connect these two fractions, while cellulose remains mainly unaffected. This pretreatment also causes lignocellulose material to swell, increasing pore size and surface area, while decreasing the degree of polymerization (DP) and crystallinity $(\mathrm{CrI})$ of the cellulose. Several studies using $\mathrm{NaOH}$ pretreatment under a variety of conditions were reviewed to highlight the progress and the limitations of this particular pretreatment option. These studies have shown the importance of adapting the pretreatment conditions to match the source and nature of the lignocellulose. Sodium hydroxide pretreatment is more effective on herbaceous crops such as grasses and agricultural residues, but under the right conditions $\mathrm{NaOH}$ pretreatment can be just as effective on woody biomass, especially extremely recalcitrant softwoods such as spruce.

\section{ACKNOWLEDGEMENTS}

The authors gratefully acknowledge the financial support of the Biomass Research and Development Initiative (Grant No. 2011-10006-30363). The investigation reported in this study (No. 12-05-115) is a part of a project of the Kentucky Agricultural Experiment Station and is published with the approval of the director.

\section{REFERENCES}

Adler, E. (1977). Lignin chemistry: Past, present, and future. Wood Sci. and Tech., 11(3), 169-218. http://dx.doi.org/10.1007/BF00365615.

Balat, M., Balat, H., \& Oz, C. (2008). Progress in bioethanol processing. Progress in Energy and Combustion Sci., 34(5), 551573. http://dx.doi.org/10.1016/j.pecs.2007.11.001.

Bruice, P. Y. (2004). Organic Chemistry (4th ed.). Upper Saddle River, N.J.: Prentice Hall.

Buranov, A. U., \& Mazza, G. (2008). Lignin in straw of herbaceous crops. Ind. Crops and Products, 28(3), 237-259. http://dx.doi.org/10.1016/j.indcrop.2008.03.008.

Cantarella, M., Cantarella, L., Gallifuoco, A., Spera, A., \& Alfani, F. (2004). Effect of inhibitors released during steam-explosion treatment of poplar wood on subsequent enzymatic hydrolysis and SSF. Biotech. Progress, 20(1), 200-206. http://dx.doi.org/10.1021/bp0257978.

Carey, F. A. (2000). Organic Chemistry (4th ed.). New York, N.Y.: McGraw-Hill College.

Carvalheiro, F., Duarte, L. C., \& Girio, F. M. (2008). Hemicellulose biorefineries: A review on biomass pretreatments. J. Sci. and Ind. Res., 667(11), 849-864.

Chandra, R. P., Bura, R., Mabee, W. E., Berlin, A., Pan, X., \& Saddler, J. N. (2007). Substrate pretreatment: The key to effective enzymatic hydrolysis of lignocellulosics? Biofuels. Advances in Biochemical Engineering and Biotechnology, Vol. 108 (pp. 67-93). Berlin, Germany: Springer-Verlag.

Chang, M. C. (2007). Harnessing energy from plant biomass. Current Opin. in Chem. Biol., 11(6), 677-684. http://dx.doi.org/10.1016/j.cbpa.2007.08.039.

Chen, M., Zhao, J., \& Xia, L. M. (2009). Comparison of four different chemical pretreatments of corn stover for enhancing enzymatic digestibility. Biomass and Bioenergy, 33(10), 1381-
1385. http://dx.doi.org/10.1016/j.biombioe.2009.05.025.

Cheng, J. (Ed.). (2010). Biomass to Renewable Energy Processes. Boca Raton, Fla.: CRC Press.

Cheng, Y. S., Zheng, Y., Yu, C. W., Dooley, T. M., Jenkins, B. M., \& VanderGheynst, J. S. (2010). Evaluation of high-solids alkaline pretreatment of rice straw. Appl. Biochem. and Biotech., 162(6), 1768-1784. http://dx.doi.org/10.1007/s12010-010-8958-4.

Ciolacu, D., \& Popa, V. I. (2005). Structural changes of cellulose determined by dissolution in aqueous alkali solution. Cellulose Chem. and Tech., 39(3-4), 179-188.

Cui, Z. F., Shi, J., Wan, C. X., \& Li, Y. B. (2012). Comparison of alkaline- and fungi-assisted wet storage of corn stover. Bioresource Tech., 109, 98-104.

Duguid, K. B., Montross, M. D., Radtke, C. W., Crofcheck, C. L., Wendt, L. M., \& Shearer, S. A. (2009). Effect of anatomical fractionation on the enzymatic hydrolysis of acid and alkaline pretreated corn stover. Bioresource Tech., 100(21), 5189-5195.

Eronen, P., Osterberg, M., \& Jaaskelainen, A. S. (2009). Effect of alkaline treatment on cellulose supramolecular structure studied with combined confocal Raman spectroscopy and atomic force microscopy. Cellulose, 16(2), 167-178. http://dx.doi.org/10.1007/s10570-008-9259-8.

Fengel, D., Jakob, H., \& Strobel, C. (1995). Influence of the alkali concentration on the formation of cellulose: II. Study by x-ray diffraction and FTIR spectroscopy. Holzforschung, 49(6), 505511. http://dx.doi.org/10.1515/hfsg.1995.49.6.505.

Galbe, M., \& Zacchi, G. (2007). Pretreatment of lignocellulosic materials for efficient bioethanol production. In Biofuels. Advances in Biochemical Engineering and Biotechnology Vol. 108 (pp. 41-65). Berlin, Germany: Springer-Verlag.

Girio, F. M., Fonseca, C., Carvalheiro, F., Duarte, L. C., Marques, S., \& Bogel-Lukasik, R. (2010). Hemicelluloses for fuel ethanol: A review. Bioresource Tech., 101(13), 4775-4800.

Grabber, J. H. (2005). How do lignin composition, structure, and cross-linking affect degradability? A review of cell wall model studies. Crop Sci., 45(3), 820-831. http://dx.doi.org/10.2135/cropsci2004.0191.

Gupta, R., \& Lee, Y. Y. (2010). Pretreatment of corn stover and hybrid poplar by sodium hydroxide and hydrogen peroxide. Biotech. Progress, 26(4), 1180-1186.

Hamaguchi, M., Cardoso, M., \& Vakkilainen, E. (2012). Alternative technologies for biofuels production in kraft pulp mills: Potential and prospects. Energies, 5(7), 2288-2309.

Hendriks, A., \& Zeeman, G. (2009). Pretreatments to enhance the digestibility of lignocellulosic biomass. Bioresource Tech., 100(1), 10-18.

Hodge, D. B., Karim, M. N., Schell, D. J., \& McMillan, J. D. (2008). Soluble and insoluble solids contributions to high-solids enzymatic hydrolysis of lignocellulose. Bioresource Tech., 99(18), 8940-8948.

Ishikura, Y., Abe, K., \& Yano, H. (2010). Bending properties and cell wall structure of alkali-treated wood. Cellulose, 17(1), 4755. http://dx.doi.org/10.1007/s10570-009-9360-7.

Jørgensen, H., Kristensen, J. B., \& Felby, C. (2007). Enzymatic conversion of lignocellulose into fermentable sugars: Challenges and opportunities. Biofuels Bioproducts and Biorefining, 1(2), 119-134.

Kadam, K. L., Chin, C. Y., \& Brown, L. W. (2008). Flexible biorefinery for producing fermentation sugars, lignin, and pulp from corn stover. J. Ind. Microbiol. and Biotech., 35(5), 331341. http://dx.doi.org/10.1007/s10295-008-0322-0.

Kim, S., \& Holtzapple, M. T. (2006). Effect of structural features on enzyme digestibility of corn stover. Bioresource Tech., 97(4), 583-591.

Kim, Y., Ximenes, E., Mosier, N. S., \& Ladisch, M. R. (2011). Soluble inhibitors/deactivators of cellulase enzymes from 
lignocellulosic biomass. Enzyme and Microbial Tech., 48(4-5), 408-415.

Knill, C. J., \& Kennedy, J. F. (2003). Degradation of cellulose under alkaline conditions. Carbohydrate Polymers, 51(3), 281-300. http://dx.doi.org/10.1016/S0144-8617(02)00183-2.

Kristensen, J. B., Felby, C., \& Jørgensen, H. (2009). Yielddetermining factors in high-solids enzymatic hydrolysis of lignocellulose. Biotech. for Biofuels, 2, 11.

Kumar, R., Mago, G., Balan, V., \& Wyman, C. E. (2009). Physical and chemical characterizations of corn stover and poplar solids resulting from leading pretreatment technologies. Bioresource Tech., 100(17), 3948-3962.

Lapierre, C., Pollet, B., \& Rolando, C. (1995). New insights into the molecular architecture of hardwood lignins by chemical degradative methods. Res. on Chem. Intermediates, 21(3-5), 397-412. http://dx.doi.org/10.1007/BF03052266.

Lee, D., Owens, V. N., Boe, A., \& Jeranyama, P. (2007). Composition of herbaceous biomass feedstocks. SGINC1-07 . Brookings, S.D.: South Dakota State University, North Central Sun Grant Center.

Li, Y., Ruan, R., Chen, P. L., Liu, Z., Pan, X., Lin, X., Liu, Y., Mok, C. K., Yang, T. (2004). Enzymatic hydrolysis of corn stover pretreated by combined dilute alkaline treatment and homogenization. Trans. ASAE, 47(3), 821-825. http://dx.doi.org/10.13031/2013.16078.

Lora, J. H., \& Glasser, W. G. (2002). Recent industrial applications of lignin: A sustainable alternative to nonrenewable materials. $J$. Polymers and Environ., 10(1-2), 39-48. http://dx.doi.org/10.1023/A:1021070006895.

Macdonald, D. G., Bakhshi, N. N., Mathews, J. F., Roychowdhury, A., Bajpai, P., \& Mooyoung, M. (1983). Alkali treatment of corn stover to improve sugar production by enzymatic hydrolysis. Biotech. and Bioeng., 25(8), 2067-2076. http://dx.doi.org/10.1002/bit.260250815.

Machell, G., Richards, G. N., \& Sephton, H. H. (1957). The alkaline degradation of cellulose. Chem. and Ind., 15, 467-469.

McIntosh, S., \& Vancov, T. (2011). Optimisation of dilute alkaline pretreatment for enzymatic saccharification of wheat straw. Biomass and Bioenergy, 35(7), 3094-3103. http://dx.doi.org/10.1016/j.biombioe.2011.04.018.

Menon, V., \& Rao, M. (2012). Trends in bioconversion of lignocellulose: Biofuels, platform chemicals, and biorefinery concept. Progress in Energy and Combustion Sci., 38(4), 522550 .

Mirahmadi, K., Kabir, M. M., Jeihanipour, A., Karimi, K., \& Taherzadeh, M. J. (2010). Alkaline pretreatment of spruce and birch to improve bioethanol and biogas production. Bioresources, 5(2), 928-938.

Mittal, A., Katahira, R., Himmel, M. E., \& Johnson, D. K. (2011). Effects of alkaline or liquid-ammonia treatment on crystalline cellulose: Changes in crystalline structure and effects on enzymatic digestibility. Biotech. for Biofuels, 4, 41.

Modenbach, A. A., \& Nokes, S. E. (2012). The use of high-solids loadings in biomass pretreatment: A review. Biotech. and Bioeng., 109(6), 1430-1442. http://dx.doi.org/10.1002/bit.24464.

Mosier, N., Wyman, C., Dale, B., Elander, R., Lee, Y. Y., Holtzapple, M., \& Ladisch, M. (2005). Features of promising technologies for pretreatment of lignocellulosic biomass. Bioresource Tech., 96(6), 673-686.

Moxley, G., \& Zhang, Y. H. (2007). More accurate determination of acid-labile carbohydrates in lignocellulose by modified quantitative saccharification. Energy and Fuels, 21(6), 36843688. http://dx.doi.org/10.1021/ef7003893.

O'Sullivan, A. C. (1997). Cellulose: The structure slowly unravels. Cellulose, 4(3), 173-207.
http://dx.doi.org/10.1023/A:1018431705579.

Petridis, L., Schulz, R., \& Smith, J. C. (2011). Simulation analysis of the temperature dependence of lignin structure and dynamics. J. American Chem. Soc., 133(50), 20277-20287. http://dx.doi.org/10.1021/ja206839u.

Qing, Q., Yang, B., \& Wyman, C. E. (2010). Xylooligomers are strong inhibitors of cellulose hydrolysis by enzymes. Bioresource Tech., 101(24), 9624-9630.

Ragauskas, A. J., Williams, C. K., Davison, B. H., Britovsek, G., Cairney, J., Eckert, C. A., Frederick, W. J., Hallett, J. P., Leak, D. J., Liotta, C. L., Mielenz, J. R., Murphy, R., Templer, R., \& Tschaplinski, T. (2006). The path forward for biofuels and biomaterials. Science, 311(5760), 484-489. http://dx.doi.org/10.1126/science.1114736.

Shimizu, S., Yokoyama, T., Akiyama, T., \& Matsumoto, Y. (2012). Reactivity of lignin with different composition of aromatic syringyl/guaiacyl structures and erythro/threo side chain structures in -O-4 type during alkaline delignification: As a basis for the different degradability of hardwood and softwood lignin. J. Agric. and Food Chem., 60(26), 6471-6476. http://dx.doi.org/10.1021/jf301329v.

Sills, D. L., \& Gossett, J. M. (2012). Using FTIR spectroscopy to model alkaline pretreatment and enzymatic saccharification of six lignocellulosic biomasses. Biotech. and Bioeng., 109(4), 894903. http://dx.doi.org/10.1002/bit.24376.

Sticklen, M. B. (2007). Feedstock crop genetic engineering for alcohol fuels. Crop Sci., 47(6), 2238-2248. http://dx.doi.org/10.2135/cropsci2007.04.0212.

Varga, E., Szengyel, Z., \& Reczey, K. (2002). Chemical pretreatments of corn stover for enhancing enzymatic digestibility. Appl. Biochem. and Biotech., 98-100, 73-87. http://dx.doi.org/10.1385/ABAB:98-100:1-9:73.

Wan, C. X., Zhou, Y. G., \& Li, Y. B. (2011). Liquid hot water and alkaline pretreatment of soybean straw for improving cellulose digestibility. Bioresource Tech., 102(10), 6254-6259.

Werpy, T., \& Peterson, G. (2004). Top value-added chemicals from biomass: Volume I. Results of screening for potential candidates from sugars and synthesis gas . Golden, Colo.: National Renewable Energy Laboratory.

Whistler, R. L., \& Bemiller, J. N. (1958). Alkaline degradation of polysaccharides. Advances in Carbohydrate Chem., 13, 289329. http://dx.doi.org/10.1016/S0096-5332(08)60359-8.

Wu, L., Arakane, M., Ike, M., Wada, M., Takai, T., Gau, M., \& Tokuyasu, K. (2011). Low-temperature alkali pretreatment for improving enzymatic digestibility of sweet sorghum bagasse for ethanol production. Bioresource Tech., 102(7), 4793-4799.

Xu, J. L., Cheng, J. J., Sharma-Shivappa, R. R., \& Burns, J. C. (2011). Sodium hydroxide pretreatment of switchgrass for ethanol production. Energy and Fuels, 25(10), 4796-4802. http://dx.doi.org/10.1021/ef201130d.

Zhang, Y. H., \& Lynd, L. R. (2004). Toward an aggregated understanding of enzymatic hydrolysis of cellulose: Noncomplexed cellulase systems. Biotech. and Bioeng., 88(7), 797-824. http://dx.doi.org/10.1002/bit.20282.

Zhao, X. B., Zhang, L. H., Liu, \& H., D. (2012). Biomass recalcitrance: Part I. The chemical compositions and physical structures affecting the enzymatic hydrolysis of lignocellulose. Biofuels Bioproducts and Biorefining, 6(4), 465-482. http://dx.doi.org/10.1002/bbb.1331.

Zhao, Y. L., Wang, Y., Zhu, J. Y., Ragauskas, A., \& Deng, Y. L. (2008). Enhanced enzymatic hydrolysis of spruce by alkaline pretreatment at low temperature. Biotech. and Bioeng., 99(6), 1320-1328. http://dx.doi.org/10.1002/bit.21712. 